\title{
Tamarix as Habitat for Birds: Implications for Riparian Restoration in the Southwestern United States
}

\author{
Mark K. Sogge, ${ }^{1,3}$ Susan J. Sferra, ${ }^{2}$ and Eben H. Paxton ${ }^{1}$
}

\begin{abstract}
Exotic vegetation has become a major habitat component in many ecosystems around the world, sometimes dramatically changing the vegetation community structure and composition. In the southwestern United States, riparian ecosystems are undergoing major changes in part due to the establishment and spread of the exotic Tamarix (saltcedar, tamarisk). There are concerns about the suitability of Tamarix as habitat for birds. Although Tamarix habitats tend to support fewer species and individuals than native habitats, Arizona Breeding Bird Atlas data and Birds of North America accounts show that 49 species use Tamarix as breeding habitat. Importantly, the relative use of Tamarix and its quality as habitat vary substantially by geographic location and bird species. Few studies have examined how breeding in Tamarix actually affects bird survivorship and productivity; recent research on Southwestern Willow Flycatchers has found no negative effects
\end{abstract}

from breeding in Tamarix habitats. Therefore, the ecological benefits and costs of Tamarix control are difficult to predict and are likely to be species specific and site specific. Given the likelihood that high-quality native riparian vegetation will not develop at all Tamarix control sites, restoration projects that remove Tamarix but do not assure replacement by high-quality native habitat have the potential to reduce the net riparian habitat value for some local or regional bird populations. Therefore, an assessment of potential negative impacts is important in deciding if exotic control should be conducted. In addition, measurable project objectives, appropriate control and restoration techniques, and robust monitoring are all critical to effective restoration planning and execution.

Key words: biocontrol, Coccyzus americanus, Diorhabda, Empidonax traillii extimus, riparian birds, Tamarix.

\section{Introduction}

The issue of non-native plant species around the world is receiving increasing attention from land managers, conservation organizations, and the public. In the United States, there are many hundreds of known exotic species and the number is expected to increase over time. A small fraction of non-natives become highly invasive and cause major changes to landscapes and ecosystems (Lodge et al. 2006). Although some high-profile exotic species have been well studied, the potential impacts of many on native species, habitats, or ecosystems are not well known or documented; despite this, detrimental effects are frequently hypothesized or assumed (Catling 2005). As a result, many ecological restoration programs focus on efforts to eliminate or control non-native species specifically to improve wildlife habitat.

However, studies from multiple countries and ecosystems suggest that a more nuanced perspective is needed when evaluating the impacts of exotic vegetation on wild-

\footnotetext{
${ }^{1}$ U.S. Geological Survey, Southwest Biological Science Center, 2255 Gemini Drive, Flagstaff, AZ, 86001, U.S.A.

${ }^{2}$ Bureau of Reclamation, Phoenix Area Office, 6150 West Thunderbird Rd. Glendale, AZ, 85306, U.S.A.

${ }^{3}$ Address correspondence to M. K. Sogge, email mark_sogge@usgs.gov
}

life. In the case of avian species, research studies indicate that the response to exotic vegetation can range from negative to positive depending on the bird species, exotic plant, and ecosystem. For example, arid grasslands in the southwestern United States are dominated in many areas by invasive grasses, and some studies have linked exotics to reduced abundance and richness of bird communities (Flanders et al. 2006) or lower nest success (Lloyd \& Martin 2005; Ortega et al. 2006). However, in other areas where they provide the same structure as native habitat, exotic grasses can serve as important habitat of equal quality in terms of reproductive success (Jones \& Bock 2005). Likewise, grassland birds in Argentina (Isacch et al. 2005) and Brazil (Francisco 2006) occupy exotic grasslands that effectively increase the amount of habitat available to them. Similarly, exotic shrubs can provide important nesting substrate that decrease nest predation in some areas, such as for the Veery (Catharus fuscescens) in forests of the eastern United States (Heckscher 2004; Schmidt et al. 2005) but not for others such as the Blackcap (Sylvia atricapilla) in the Czech Republic (Remes 2003). The structure of vegetation, native or exotic, may be more important to birds than the actual species composition (Hausner et al. 2002; Jones \& Bock 2005), and different species of birds will respond differently (Gjerde \& Saetersdal 1997). The complexity of 
responses by bird communities to exotics in different ecosystems around the world suggests that negative impacts by exotics cannot be universally assumed; rather, evaluation of impacts should be conducted species by species with attention to geographic differences.

One target of many riparian restoration efforts, particularly in the southwestern United States, is a complex of tree-shrub species in the genus Tamarix (saltcedar; tamarisk; Tamarix ramosissima, $T$. chinensis, or the hybrid T. ramosissima $\times$ chinensis; Gaskin \& Schaal 2002; hereafter referred to as Tamarix). A native tree-shrub of Eurasia, Tamarix spreads after being intentionally introduced in the western United States in the 1800s and now covers over one-half million hectare in at least 23 states (Zavaleta 2000); its distribution in Mexico is poorly documented but extends at least as far south as the Yaqui River Valley in Sonora (Glenn \& Nagler 2005). Due to its deep root system, tolerance for saline conditions, and prolific seed production, Tamarix has thrived throughout much of the American West, most commonly where flows and spring floods have declined, the water table has become too deep, and soils are too salty for mesic native vegetation to survive (Lovich \& De Gouvenain 1998; Glenn \& Nagler 2005; Shafroth et al. 2005). Because the spread of Tamarix occurred concurrently with the decline of native riparian habitats in the West, Tamarix is often viewed as a key factor in that decline and the cause of associated reductions in many riparian breeding birds (DeLoach et al. 2000). Accordingly, many Tamarix management and control programs include the objective of improving riparian bird habitat.

Given the vast extent of Tamarix on the landscape and the large number of riparian restoration efforts that are focused on its eradication or control, it is important to fully understand the benefits and costs of Tamarix management on birds. In this article, our goal is to highlight the fact that many bird species do breed in Tamarix habitats and that there are relatively few data available to suggest that birds experience negative ramifications in doing so. Therefore, restoration projects that remove Tamarix but do not assure replacement by high-quality native habitat have the potential to reduce the net riparian habitat value for some local or regional bird populations. In presenting these considerations, we are not suggesting that Tamarix is preferable to or provides the same habitat value as native riparian vegetation; indeed, it likely has lower value than native habitats in most situations. Nor are we proposing that Tamarix control is, in and of itself, unnecessary or unwise. Rather, we believe that objective-based planning, use of the right control and restoration techniques, and post-management monitoring are necessary to maximize the benefits and minimize the unintended consequences of Tamarix management on avifauna and other wildlife.

\section{How Extensive Is Bird Use of Tamarix?}

A first step to understanding potential effects of Tamarix management on southwestern riparian avifauna is to eval- uate whether birds use or avoid the exotic habitat. Multiple studies have documented that Tamarix can provide important habitat for regional breeding bird communities in some parts of the American Southwest. Hunter et al. (1988) were among the first to describe the riparian bird communities breeding in Tamarix along the Pecos River and the Rio Grande in New Mexico and the lower Colorado River in Arizona and California. Although birds were overall less abundant in Tamarix and some species were lacking compared to similar native riparian habitats, Tamarix stands accounted for a significant amount of riparian habitat in those regions, resulting in larger local and regional riparian bird populations than would have been present in the absence of Tamarix (Hunter et al. 1988). Similarly, Livingston and Schemnitz (1996) reported that Tamarix along the Pecos River in New Mexico supported a diverse and abundant breeding bird community, having three to four times the number of birds than did the adjacent grassland or grassland/shrub habitats that would be present if Tamarix did not occur there. Further west along the Colorado River in the Grand Canyon, Tamarix flourished and dramatically increased along the river edge following construction of Glen Canyon Dam, and the riparian bird community increased in abundance and diversity (Brown et al. 1987). Several of the bird species that benefited from increased Tamarix riparian habitats were species of regional and national concern (Holmes et al. 2005). Sogge et al. (2005) reported that the area and volume of Tamarix habitat patches within the Grand Canyon were among the best positive predictors of bird species abundance, richness, and diversity along the river corridor. In yet another drainage, Fleishman et al. (2003) reported that the species richness of native birds (up to 45 breeding species per site) along the Muddy River in the Mojave Desert was best predicted by total vegetation volume, and bird species richness was not negatively affected by invasion of non-native plants (including Tamarix), provided that the vegetation community retained structural diversity. In the Colorado River delta in Mexico, bird diversity was more positively influenced by the presence of surface water than by whether habitat was composed of Tamarix or native riparian vegetation (Hinojosa-Huerta 2006). However, bird abundance and diversity may be lower in Tamarix than it would be in native-dominated riparian in the same area. The lower Colorado River in Arizona and Mexico is one such area, where avifauna is greatly reduced in Tamarix-dominated areas compared with native-dominated areas, and some riparian species are apparently absent (Hunter et al. 1988; Hinojosa-Huerta et al. 2004; Hinojosa-Huerta 2006). Thus, local factors apparently influence the habitat quality of Tamarix, and Tamarix appears to provide lower-quality habitat than native riparian in certain areas.

Although studies have shown that bird communities can be supported by Tamarix in at least some locations, it is reasonable to expect that the use and value of Tamarix as habitat may vary from species to species. To evaluate 
the use of Tamarix among individual bird species, we reviewed nesting habitat data from the recently completed Arizona Breeding Bird Atlas (Corman \& Wise-Gervais 2005) and the Birds of North America species accounts (http://bna.birds.cornell.edu/BNA/). Of the 29 species considered by the Arizona Breeding Bird Atlas as lowland riparian breeders (Table 1$), 22(76 \%)$ were recorded by atlas observers as breeding in Tamarix. Our text search of the online Birds of North America using the key words "saltcedar," "salt cedar," "tamarisk," and "tamarix" found records of 32 species of birds breeding in Tamarix in at least some parts of their range (Table 2). Collectively, the Arizona Breeding Bird Atlas and Birds of North America accounts identified 49 species as having bred in Tamarix to varying degrees. Atlas and species accounts generally lacked quantitative data for a robust comparison of differences of use among species, and there is virtually no information for assessing Tamarix use versus availability on the landscape. Overall, however, the number of bird species that do breed in Tamarix suggests a substantial habitat value for a diverse group of birds.

Only two southwestern riparian breeding bird species, both of conservation concern, have been the subject of

Table 1. Lowland riparian breeding birds in Arizona, based on habitat descriptions in the Arizona Breeding Bird Atlas (Corman and Wise-Gervais 2005).

\begin{tabular}{ll}
\hline Abert's Towhee* & Pipilo aberti \\
American Dipper* & Cinclus mexicanus \\
Anna's Hummingbird & Calypte anna \\
Bell's Vireo* & Vireo bellii \\
Belted Kingfisher* & Ceryle alcyon \\
Bewick's Wren* & Thryomanes bewickii \\
Black Phoebe* & Sayornis nigricans \\
Black-chinned Hummingbird* & Archilochus alexandri \\
Blue Grosbeak* & Guiraca caerulea \\
Broad-billed Hummingbird & Cynanthus latirostris \\
Brown-crested Flycatcher & Myiarchus tyrannulus \\
Brown-headed Cowbird* & Molothrus ater \\
Bullock's Oriole* & Icterus bullockii \\
Cliff Swallow* & Petrochelidon pyrrhonota \\
Common Yellowthroat* & Geothlypis trichas \\
Hooded Oriole & Icterus cucullatus \\
Indigo Bunting* & Passerina cyanea \\
Lazuli Bunting* & Passerina amoena \\
Lucy's Warbler* & Vermivora luciae \\
Northern Beardless-Tyrannulet & Camptostoma imberbe \\
Northern Rough-winged Swallow* & Stelgidopteryx serripennis \\
Red-winged Blackbird* & Agelaius phoeniceus \\
Song Sparrow* & Melospiza melodia \\
Summer Tanager* & Piranga rubra \\
Thick-billed Kingbird & Tyrannus crassirostris \\
Willow Flycatcher* & Empidonax traillii \\
Yellow Warbler* & Dendroica petechia \\
Yellow-billed Cuckoo & Coccyzus americanus \\
Yellow-breasted Chat* & Icteria virens \\
\hline Ovell, 22 of s9ses (inded by asto &
\end{tabular}

Overall, 22 of 29 species (indicated by asterisks) were recorded as breeding in Tamarix habitats. The relative degree of Tamarix use varied by species and could not be readily quantified because atlas search efforts were not proportional among habitat types.
Table 2. Avian species documented using Tamarix as breeding habitat, based on habitat descriptions in the Birds of North America (http://bna.birds.cornell.edu/BNA/).
Abert's Towhee

Ash-throated Flycatcher

Bell's Vireo

Bewick's Wren

Black-crowned Night Heron

Black-tailed Gnatcatcher

Blue Grosbeak

Brown Thrasher

Bullock's Oriole

Cactus Wren

Cattle Egret

Chihuahuan Raven

Common Moorhen

Common Yellowthroat

Crissal Thrasher

Elf Owl

Gambel's Quail

Greater Roadrunner

Lucy's Warbler

Mourning Dove

Pyrrhuloxia

Roseate Spoonbill

Song Sparrow

Summer Tanager

Tri-colored Blackbird

Verdin

White-faced Ibis

White-winged Dove

Willow Flycatcher

Yellow Warbler

Yellow-breasted Chat

Yellow-headed Blackbird
Pipilo aberti

Myiarchus cinerascens

Vireo bellii

Thryomanes bewickii

Nycticorax nycticorax

Polioptila melanura

Guiraca caerulea

Toxostoma rufum

Icterus bullockii

Campylorhynchus

brunneicapillus

Bubulcus ibis

Corvus cryptoleucus

Gallinula chloropus

Geothlypis trichas

Toxostoma crissale

Micrathene whitneyi

Callipepla gambelii

Geococcyx californianus

Vermivora luciae

Zenaida macroura

Cardinalis sinuatus

Ajaia ajaja

Melospiza melodia

Piranga rubra

Agelaius tricolor

Auriparus flaviceps

Plegadis chihi

Zenaida asiatica

Empidonax traillii

Dendroica petechia

Icteria virens

Xanthocephalus

xanthocephalus
The relative degree of Tamarix use varied by species but was not quantitatively described in most species accounts.

enough research to evaluate whether Tamarix is used as breeding habitat across most of their ranges and to what degree. One such species is the Yellow-billed Cuckoo (Coccyzus americanus), the western United States population of which is a candidate for federal endangered species status due to riparian habitat loss. It generally prefers mature riparian habitats and is most commonly associated with cottonwood (Populus fremontii) or other native forests (Hughes 1999). However, Yellow-billed Cuckoos breed extensively in the dense Tamarix stands along parts of the Pecos River in New Mexico (Hunter et al. 1988; Livingston \& Schemnitz 1996). Although the cuckoos in this region are not considered to be of the candidate western population, Howe (1986) described how a large cuckoo breeding population developed along the Pecos River by the mid-1980s and linked this to the conversion of riverbank grasslands and shrublands to Tamarix. Livingston and Schemnitz (1996) later reported that dense Tamarix stands are important habitat for the cuckoo along the Pecos River. Although there are no specific studies on 
the relative breeding success of cuckoos in Tamarix, the notable population expansion along the Pecos River (Howe 1986) suggests that successful breeding did occur. However, the frequency that Yellow-billed Cuckoos use Tamarix clearly varies geographically. Within New Mexico, use is common on the Pecos River, more limited on the Rio Grande (and usually associated with a native component), and absent on the Gila River (Howe 1986; Hunter et al. 1988; Woodward et al. 2003). More broadly, Yellow-billed Cuckoos have not been found breeding in Tamarixdominated habitats outside of New Mexico (Johnson et al. 2006, 2007), though Tamarix may be a component of the habitat patch. This suggests, as with other bird species, that the suitability of Tamarix as breeding habitat for cuckoos varies across the landscape, with local environmental factors determining its relative habitat value.

Although documenting breeding within Tamarix habitats is the first step in understanding Tamarix's value to bird species, bird presence does not necessarily equate to habitat quality (van Horne 1983), and it is possible that poor-quality habitat could attract birds (i.e., an ecological trap; Robertson \& Hutto 2006). To truly evaluate the quality of Tamarix as habitat requires intensive research to assess a suite of factors, such as measures of lifetime fitness (e.g., productivity and survivorship), physiological condition, and food availability. To date, only one bird species, the Southwestern Willow Flycatcher (Empidonax traillii extimus), has received enough research attention to evaluate habitat quality of Tamarix at this level. A federally endangered species and neotropical migrant, the flycatcher breeds in dense, generally mesic riparian areas throughout most of the southwestern United States (USFWS 2002). Although most Southwestern Willow Flycatchers breed in riparian patches dominated by native trees such as willow (Salix spp.), roughly $25 \%$ of known breeding territories are in habitats dominated by Tamarix and another $25 \%$ are in native habitats where Tamarix and other exotics provide more than $10 \%$ of the habitat structure (Durst et al. 2006). Likely, the flycatcher selects its breeding sites based on structural characteristics more so than species composition (USFWS 2002). Because the flycatcher breeds in both native and exotic habitat types, often in the same drainage, it is possible to evaluate whether flycatchers breeding in Tamarix habitats might suffer from a poor food base, reduced survivorship, and low productivity or whether Tamarix is functionally of similar quality to flycatchers as native habitat. Recent research on flycatchers breeding in Tamarix has found no evidence of a depauperate diet (DeLay et al. 1999; Drost et al. 2001; Durst 2004), and studies by Owen et al. (2005) concluded that there was no indication that birds breeding in Tamarix were suffering negative physiological effects compared to those in native habitats. Similarly, Sogge et al. (2006) found no evidence of reduced survivorship or productivity among Southwestern Willow Flycatchers breeding in Tamarix habitats compared to native vegetation at Roosevelt Lake in central Arizona. Clearly, Tamarix can provide similar habitat quality as native vegetation for Southwestern Willow Flycatchers in at least some locations and is considered an important habitat for recovery of this species (USFWS 2002). On the other hand, there are areas where Tamarix is dominant and widespread and in which flycatchers bred historically (e.g., the lower Colorado River near Yuma, Arizona) but are absent from today. Additional research is needed to evaluate whether Tamarix in these unoccupied areas does not provide the necessary ecological functions and environmental conditions required by flycatchers or whether Southwestern Willow Flycatchers do not have the population numbers necessary to occupy all suitable habitat present in the southwest.

In general, Tamarix use is most common among riparian generalists (i.e., those birds that breed in a variety of different native riparian habitat types), but Tamarix is clearly not a suitable habitat for all native riparian birds. Those that have very specific habitat requirements, such as woodpeckers, secondary-cavity nesters, or raptors requiring large branches to support their nests, often do not adapt well to Tamarix and hence can be reduced or absent in Tamarix stands (Anderson et al. 1977; Hunter et al. 1988; Ellis 1995; Walker 2006). Some species do breed in Tamarix but in reduced density in some circumstances or not at all in others (Rosenberg et al. 1991; DeLoach et al. 2000). Therefore, Tamarix will not have the same habitat value to all bird species, nor even to the same species in different areas. A well-known example of this is the lower Colorado River near the United States/Mexico International Boundary where changing water regimes have impacted native riparian forests and led to vast Tamarix stands, contributing to the decline in riparian bird abundance and diversity (Hunter et al. 1988; Rosenberg et al. 1991; Hinojosa-Huerta et al. 2004; Hinojosa-Huerta 2006). Thus, a key point to remember is that different species will respond to different Tamarix habitats in different ways, and the question of Tamarix as bird habitat cannot be addressed from a simple "yes/no" perspective.

\section{Why Do Some Birds Use Tamarix?}

Tamarix does support riparian-dependent birds that may not be present or might otherwise have declined more rapidly without it (Howe 1986; Hunter et al. 1988; Rosenberg et al. 1991; Ellis 1995, 1997; Rodriguez 2006). In some areas, Tamarix can provide the vertical structure, foliar cover, and food resources needed by a number of species dependent upon riparian vegetation and serves as an acceptable substitute where fire, lack of water, and salinity are preventing establishment of native riparian vegetation (Shafroth et al. 2005). Geographic factors, the type and structure of adjacent and interspersed habitats, and stand characteristics are key in determining the habitat value of Tamarix (Hunter et al. 1988; Livingston \& Schemnitz 1996; Walker 2006). Thus, in some places, Tamarix can provide the structural complexity and microhabitat characteristics 
needed by riparian birds; however, in other areas, low elevation, extremely hot desert climates, and lack of proximity to surface water can result in Tamarix stand structure and microclimate that is of lower habitat value for birds.

For insectivorous birds, a crucial component of habitat quality is the arthropod communities that a particular habitat can support. Studies conducted to date suggest that the arthropod communities supported by Tamarix vary geographically, which may be one reason why birds will occupy Tamarix in some areas but not in others. Along the middle Rio Grande in New Mexico, arthropod species richness and abundance were similar in Tamarix and cottonwood habitats (Ellis et al. 2000). On the lower Colorado River, several of the most common insect families in riparian habitat occur in comparable or greater abundance in Tamarix than in most native vegetation (Anderson et al. 2004), and at Roosevelt Lake in Arizona, Durst (2004) found no difference in invertebrate biomass in native versus Tamarix patches. However, other studies (Yong \& Finch 1997; DeLoach et al. 2000; Dudley \& DeLoach 2004; Nelson \& Wydoski 2008) found evidence for reduced arthropods in Tamarix habitats and noted that this could reduce habitat quality for birds. This variability suggests that a suite of factors-including internal patch structure and heterogeneity, adjacent habitats and land uses, proximity to water or saturated soils, attractiveness to pollinating insects, understory plant characteristics, climate, and local environmental characteristics-may be the primary determinants of invertebrate abundance and diversity within individual Tamarix habitats.

\section{Could Tamarix Control Negatively Impact Some Birds?}

The relative value of Tamarix control as part of riparian restoration to benefit birds will vary based on geography, stand characteristics, and, perhaps most importantly, the type of habitat that would replace the Tamarix. Tamarix likely seldom supports the same wildlife species richness, guilds, and population sizes as native habitat, but it can fulfill an important habitat role for some species (USFWS 2002; Walker 2006), especially in areas where degraded riparian systems preclude the establishment of native vegetation. These considerations move us beyond the simple question of whether there are as many birds in Tamarix as in native riparian habitats to the more relevant restoration and conservation issue of whether a given area of Tamarix provides higher net riparian habitat value than does the replacement habitat. If Tamarix is replaced with a comparable amount of quality native riparian vegetation, there would presumably be a net benefit. However, if an area of Tamarix that currently supports riparian breeding birds is replaced by nonriparian vegetation or by only a fractional amount of native riparian habitat, there may be a net loss of riparian habitat value (Shafroth et al. 2005) and possible local/regional loss of riparian birds (Fleishman et al. 2003; Walker 2006). Without careful restoration planning, execution, and follow-up, it is also possible that Tamarix will be replaced by other invasive vegetation that has even lower habitat value or greater negative effects (D'Antonio \& Meyerson 2002; Harms \& Hiebert 2006; Shafroth et al. 2008).

Concerns of habitat loss are especially acute for endangered and sensitive species. Howe (1986) considered past and future large-scale Tamarix control on the Pecos River as a possible threat to the persistence of Yellow-billed Cuckoos there. Livingston and Schemnitz (1996) stated that cuckoos would lose essential habitat when Tamarix is removed along this river. Subsequently, cuckoos have all but disappeared in the lower Pecos valley from Six-Mile Dam near Carlsbad to the border of Texas following a large-scale Tamarix removal project from 1999 through 2006 (Travis 2005; Hart et al. 2006), and Williams and Travis (2003) concluded that Tamarix defoliation from aerial spraying, mechanical removal, and biocontrol continues to be a threat. Similarly, the Southwestern Willow Flycatcher recovery plan (USFWS 2002) expressed concerns about large-scale Tamarix control or removal at occupied flycatcher sites and noted that extensive defoliation via biocontrol insects, even without complete Tamarix mortality, could reduce the vegetative cover at flycatcher breeding sites sufficiently to render them unsuitable or inferior to their precontrol state.

To explore whether additional species have the potential to be negatively affected by widespread Tamarix control, we compiled a list (Table 3 ) of riparian birds that breed in Tamarix-dominated habitats ( $>75 \%$ Tamarix) in at least part of their range within Arizona and New Mexico (Bureau of Reclamation, unpublished data; Hunter et al. 1988; McKernan \& Braden 2002; Corman \& Wise-Gervais 2005; Sogge et al. 2005). The resulting list includes nine additional species (beyond the cuckoo and the flycatcher), many of which are considered priority species by Partners in Flight (Rich et al. 2004; Intermountain West Joint Venture 2005; Sonoran Joint Venture Technical Committee 2006) or birds of management concern by the USFWS (2004). Whether these or other species would actually experience local population reductions depends in large part on the geographic location and the extent and pace of both Tamarix loss and the development of replacement habitat, all of which are influenced by a number of physical, ecologi$\mathrm{cal}$, and restoration technique factors (Shafroth et al. 2008).

Even when restoration will lead to replacement of Tamarix with native riparian vegetation, it is important to consider the rate at which this will occur. In desert environments, removal of Tamarix may be followed by long-term depauperate plant communities, especially where sufficient surface water, groundwater, and flooding regimes are not present (Harms \& Hiebert 2006). If Tamarix is removed rapidly but replacement riparian habitat develops only slowly, the interim loss of riparian vegetation could lead to reduction or loss of local populations of riparian birds, at least in the short-term (Fleishman et al. 2003). It is likely that most riparian bird species would become reestablished once the new riparian habitat develops and 
Table 3. Bird species that breed in habitats composed of more than $75 \%$ Tamarix within Arizona and New Mexico and therefore subject to potential local declines in population following Tamarix control.

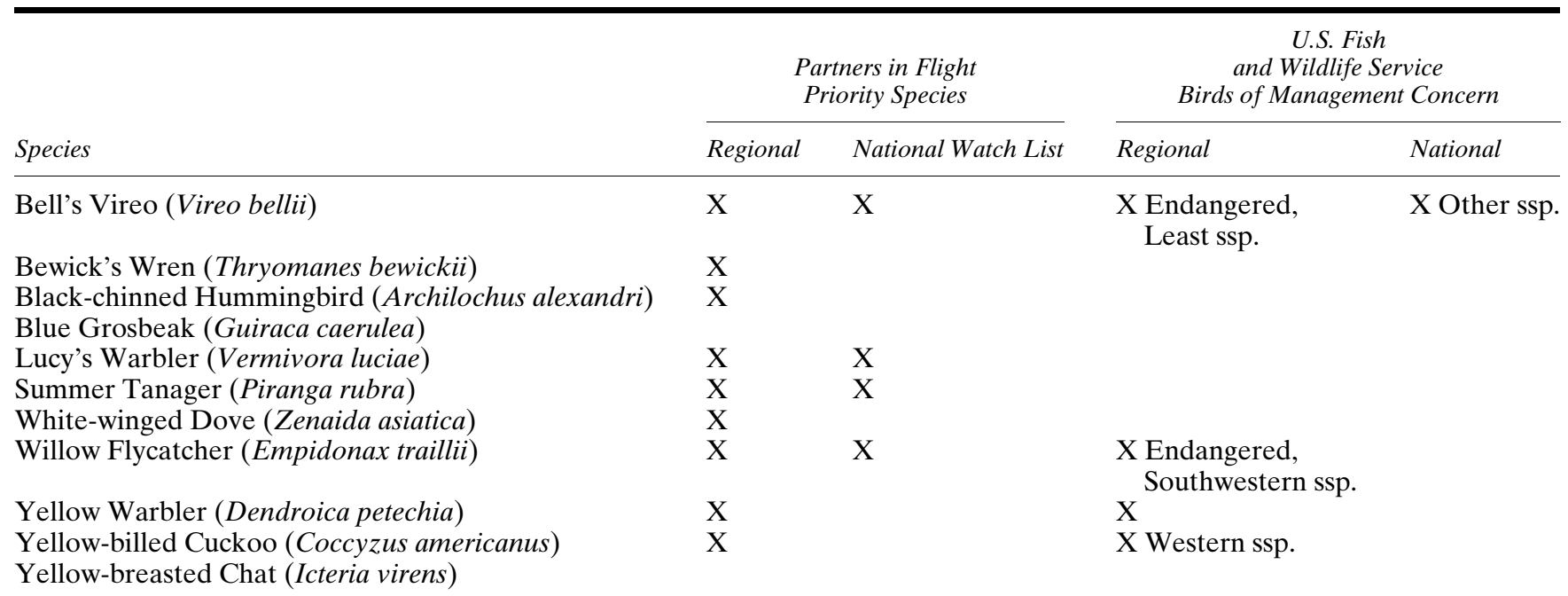

Sources: Bureau of Reclamation (unpublished data), Hunter et al. (1988), McKernan \& Braden (2002), Corman \& Wise-Gervais (2005), Sogge et al. (2005). Species with Partners in Flight (Rich et al. 2004; Intermountain West Joint Venture 2005; Sonoran Joint Venture Technical Committee 2006) or USFWS (2004) conservation priority in at least part of the Southwestern Willow Flycatcher's range are indicated by an "X."

becomes suitable, but for some rare or endangered species, even the temporary loss may be of management concern.

\section{Management Implications}

Non-native species control can be a technically and ecologically complex issue, especially when done in the context of native habitat restoration (D'Antonio \& Meyerson 2002; Harms \& Hiebert 2006; Shafroth et al. 2008). Approaching restoration by focusing only on invasive control is problematic and unlikely to prove successful; restoration plans should factor in local physical and ecological conditions and address the potential need for activities such as planting, supplemental watering, or reduction of other local stressors (Bay \& Sher 2008; Shafroth et al. 2008). A long-term riparian restoration strategy that directly manages for native species by focusing on favorable processes, rather than simply against exotics, is likely to be more successful than simple removal of Tamarix (Briggs 1996; Stromberg \& Chew 2002; Harms \& Hiebert 2006; Hinojosa-Huerta 2006).

Thus, there are many challenges to effective riparian restoration, especially at large scales, and there are no guarantees such efforts will produce the desired outcome or result in the same vegetative communities that were present before Tamarix became established (D'Antonio \& Meyerson 2002; Harms \& Hiebert 2006; Shafroth et al. 2008). Still, given amenable conditions and active restoration activities (Bay \& Sher 2008; Shafroth et al. 2008), there are places where native habitat can be restored to provide higher benefit to birds and other wildlife (Lovich \& De Gouvenain 1998; DeLoach et al. 2000). In addition, there can be negative consequences to not controlling Tamarix in some areas, such as increased or continued high fire risk, continued loss of the native vegetation at a site, establishment of Tamarix in new areas, and persistent exclusion of riparian "specialist" birds such as cavity nesters. Tamarix control may also be undertaken for reasons unrelated to habitat improvement (e.g., reduce fire risk, Shafroth et al. 2008), so the success or value of all Tamarix control projects cannot be based solely on their net benefit to birds or other wildlife.

There are a variety of techniques available for Tamarix control and riparian restoration, and different techniques vary widely in cost, the scale and rate at which they act, and the degree to which they can be targeted at or retained within a particular area. Because all these variables influence how birds will be affected by Tamarix control, it is important to use the control technique(s) best suited for a given situation or set of objectives (Shafroth et al. 2008). For example, mechanical removal or herbicides can be applied to specific sites at a relatively fine scale and even to selectively remove only a portion of the Tamarix at a given site. This approach could prove valuable when attempting to minimize impacts that might arise from large-scale loss of habitat or to allow a gradual conversion from Tamarix to native vegetation that might promote continued occupation by riparian birds (Livingston \& Schemnitz 1996; USFWS 2002; Fleishman et al. 2003). In contrast, biocontrol insects such as Diorhabda elongata can rapidly reduce Tamarix cover over very large areas at a relatively low cost (DeLoach et al. 2000) but cannot be selectively targeted. Since 2001, Diorhabda beetles defoliated approximately 50,000 ha of Tamarix at sites in Nevada, Utah, Wyoming, and Colorado, and have already dispersed approximately $60 \mathrm{~km}$ from a release site in Nevada (DeLoach 2006; DeLoach et al. 2006). Given the above, we believe that the Diorhabda beetles will probably spread widely across the southwestern United States, both naturally and with human assistance. Thus, the introduced beetle is likely to have 
geographically widespread effect on Tamarix, irrespective of whether the affected habitat is of high or low quality to bird species. Selective control may be preferable for some objectives because several studies have shown that a small increase in native habitat can have a large positive effect on the bird community (Ellis 1995; Holmes et al. 2003; van Riper et al. 2008). Ultimately, evaluation of success requires scientifically valid and statistically robust postcontrol monitoring and evaluation; the use of inappropriate techniques and response measures, or failure to consider site-specific data, can risk producing erroneous or misleading conclusions (Kus \& Beck 2003; Walker 2006). Unfortunately, most Tamarix control projects to date have not included effective or long-term avian or wildlife monitoring (Walker 2006, Nelson \& Wydoski 2008; Shafroth et al. 2008).

Globally, managers contemplating habitat restoration through the control of invasives are faced with a complex task, in part because there are still large gaps in our understanding of which exotics are truly of concern and of the relationships between wildlife and exotic plants (Fleishman et al. 2003). This creates substantial challenges in predicting the outcome of exotic plant control in terms of wildlife habitat and animal populations. The goals of biological conservation and management will be best served by a careful evaluation of whether the planned activities will entail more positive than negative ecological impacts, and embarking only on those that provide a net positive outcome. To do otherwise risks violating the long-standing credo of "first, do no harm."

\section{Implications for Practice}

- Many birds use exotic vegetation such as Tamarix as breeding habitat. For Tamarix, the degree of use varies by bird species, geographic area, and stand structure and characteristics. This variation makes it difficult to predict the ecological benefits and costs of Tamarix control or removal because the effects are likely to be species specific and site specific.

- Tamarix control has the potential to reduce local or regional populations of some riparian bird species, depending upon the scale of control, techniques used, whether higher-quality riparian habitat replaces the Tamarix, and how long it takes for replacement to occur. Removal or control of Tamarix, in the absence of effective restoration activities, may decrease the net riparian habitat value for birds.

- Decisions on whether to control exotics, and any efforts to do so, will be most effective if they are based on objective evaluation of potential positive and negative impacts, tailored to the individual site. Measurable goals and objectives are also important to the success of control and restoration projects, as are the use of appropriate techniques and robust and effective monitoring.

\section{Acknowledgments}

This work was supported by salary and research funds from the Bureau of Reclamation and the U.S. Geological Survey. Valuable data were provided by the Arizona Game and Fish Department; we especially thank T. Corman for sharing his knowledge and insights on the birds of Arizona. C. Beardmore graciously provided guidance on Partners in Flight bird prioritization. S. O. Williams, III, shared information on the status of Yellow-billed Cuckoos in New Mexico. We thank T. Dudley, K. Paxton, T. J. Tibbitts, C. van Riper, III, and two anonymous reviewers for helpful comments on earlier drafts, and L. Sogge for editorial assistance with the manuscript.

\section{LITERATURE CITED}

Anderson, B. W., A. Higgins, and R. D. Ohmart. 1977. Avian use of saltcedar communities in the Lower Colorado River Valley. Pages 128-145 in R. R. Johnson, and D. A. Jones, technical coordinators. Importance, preservation, and management of riparian habitat: a symposium. General Technical Report RM-43. U.S. Department of Agriculture, Forest Service, Fort Collins, Colorado.

Anderson, B. W., P. E. Russell, and R. D. Ohmart. 2004. Riparian vegetation: an account of two decades of experience in the arid Southwest. Avvar Books, Blythe, California.

Bay, R. F., and A. A. Sher. 2008. Success of active revegetation after Tamarix removal in riparian ecosystems of the southwestern United States: a quantitative assessment of past restoration projects. Restoration Ecology 16:113-128.

Briggs, M. 1996. Riparian ecosystem recovery in arid lands: strategies and references. University of Arizona Press, Tucson.

Brown, B. T., S. W. Carothers, and R. R. Johnson. 1987. Grand Canyon birds. University of Arizona Press, Tucson.

Catling, P. M. 2005. Effects of invasive alien plants on birds: some examples from North America. Biodiversity 6:30-39.

Corman, T., and C. Wise-Gervais, editors. 2005. Arizona breeding bird atlas. University of New Mexico Press, Albuquerque.

D'Antonio, C. D., and L. A. Meyerson. 2002. Exotic plant species as problems and solutions in ecological restoration: a synthesis. Restoration Ecology 10:703-713.

DeLay, L., D. M. Finch, S. Brantley, R. Fagerlund, M. D. Mearns, and J. F. Kelly. 1999. Arthropods of native and exotic vegetation and their associations with willow flycatchers and Wilson's warblers. Pages 216-221 in D. M. Finch, J. C. Whitney, J. F. Kelly, and S. R. Loftin, technical coordinators. Rio Grande ecosystems: linking land, water and people. Proceedings RMRS-P-7. USDA Forest Service, Rocky Mountain Research Station, Ogden, Utah.

DeLoach, C. J. 2006. Biological control of saltcedar, Russian olive, and other invasive weeds in the Western USA (409509). 2006 Annual Report, U.S. Department of Agriculture, Agricultural Research Service, Temple, Texas (available from http://www.ars.usda.gov/ research/projects) accessed 2 April 2007.

DeLoach, C. J., R. I. Carruthers, J. Lovich, T. L. Dudley, and S. D. Smith. 2000. Ecological interactions in the biological control of saltcedar (Tamarix spp.) in the U.S.: toward a new understanding. Pages 819-874 in N. R. Spencer, editor. Proceedings of X International Symposium on Biological Control, July 1999. Montana State University, Bozeman.

DeLoach, C. J., R. Milbrath, R. Carruthers, A. E. Knutson, F. Nibling, D. Eberts, et al. 2006. Overview of saltcedar biological control. Pages 92-99 in C. Aguirre-Bravo, P. J. Pellicane, D. P. Burns, and S. Draggan, editors. Monitoring science and technology symposium: unifying knowledge for sustainability in the Western hemisphere. 20-24 September 
2004, Denver, Colorado. Proceedings RMRS-P-42CD. U.S. Department of Agriculture, Forest Service, Rocky Mountain Research Station, Fort Collins, Colorado.

Drost, C. A., E. H. Paxton, M. K. Sogge, and M. J. Whitfield. 2001. Food habits of the endangered Southwestern Willow Flycatcher. USGS Report to U.S. Bureau of Reclamation, Salt Lake City, Utah. USGS Southwest Biological Science Center, Flagstaff, Arizona.

Dudley, T. L., and C. J. DeLoach. 2004. Saltcedar (Tamarix spp.), endangered species, and biological weed control—can they mix? Weed Technology 18:1542-1551.

Durst, S. L. 2004. Southwestern Willow Flycatcher potential prey base and diet in native and exotic habitats. M.S. thesis. Northern Arizona University, Flagstaff.

Durst, S. L., M. K. Sogge, H. C. English, S. O. Williams III, B. E. Kus, and S. J. Sferra. 2006. Southwestern Willow Flycatcher breeding site and territory summary-2005. U.S. Geological Survey, Southwest Biological Science Center Report to U.S. Bureau of Reclamation. USGS Southwest Biological Science Center, Flagstaff, Arizona.

Ellis, L. M. 1995. Bird use of saltcedar and cottonwood vegetation in the middle Rio Grande Valley, New Mexico. Journal of Arid Environments 30:339-349.

Ellis, L. M. 1997. Rodent communities in native and exotic riparian vegetation in the middle Rio Grande Valley of central New Mexico. Southwestern Naturalist 42:13-19.

Ellis, L. M., M. C. Molles, C. S. Crawford, and F. Heinzelmann. 2000. Surface-active arthropod communities in native and exotic riparian vegetation in the Middle Rio Grande Valley, New Mexico. Southwestern Naturalist 42:456-471.

Flanders, A. A., W. P. Kuvlesky, D. C. Ruthven, R. E. Zaiglin, R. L. Bingham, T. E. Fulbright, F. Hernandez, and L. A. Brennan. 2006. Effects of invasive exotic grasses on south Texas rangeland breeding birds. Auk 123:171-182.

Fleishman, E., N. McDonal, R. MacNally, D. D. Murphy, J. Walters, and T. Floyd. 2003. Effects of floristics, physiognomy and non-native vegetation on riparian bird communities in a Mojave Desert watershed. Journal of Animal Ecology 72:484-490.

Francisco, M. R. 2006. Breeding biology of the double-collared seedeater (Sporophila caerulescens). Wilson Journal of Ornithology 118:85-90.

Gaskin, J. F., and B. A. Schaal. 2002. Hybrid Tamarix widespread in U.S. invasion and undetected in native Asian range. Proceedings of the National Academy of Sciences 99:11256-11259.

Gjerde, I., and M. Saetersdal. 1997. Effects on avian diversity of introducing spruce Picea spp. plantations in the native pine Pinus sylvestris forests of western Norway. Biological Conservation 79:241-250.

Glenn, E. P., and P. L. Nagler. 2005. Comparative ecophysiology of Tamarix ramosissima and native trees in western U.S. riparian zones. Journal of Arid Environments 61:419-446.

Harms, R. S., and R. D. Hiebert. 2006. Vegetation response following invasive tamarisk (Tamarix spp.) removal and implications for riparian restoration. Restoration Ecology 14:461-472.

Hart, C. R., M. K. Owens, and G. W. Moore. 2006. Saltcedar management and water salvage estimates on the Pecos River in Texas, 1999-2005. Abstract from paper presented at 2006 Tamarisk Research Conference: current status and future direction. Fort Collins, Colorado. (http://www.weedcenter.org/tamarisk_conf_06/aILabstracts.pdf) accessed 2 April 2007.

Hausner, V. H., N. G. Yoccoz, K. Strann, and R. A. Ims. 2002. Changes in bird communities by planting non-native spruce in coastal birch forests of northern Norway. Ecoscience 9:470-481.

Heckscher, C. M. 2004. Veery nest sites in a mid-Atlantic Piedmont forest: vegetative physiognomy and use of alien shrubs. American Midland Naturalist 151:326-337

Hinojosa-Huerta, O. M. 2006. Birds, water, and saltcedar: strategies for riparian restoration in the Colorado River Delta. Ph.D. dissertation. University of Arizona, Tucson.
Hinojosa-Huerta, O. M., H. Iturribarria-Rojas, Y. Carrillo-Guerrero, M. de la Garza-Trevino, and E. Zamora-Hernandez. 2004. Bird conservation plan for the Colorado River Delta. Pronatura Noroeste, Direccion de Conservacion Sonora, San Luis Rio Colorado, Sonora, Mexico.

Holmes, A. L., M. E. Flannery, and G. R. Geupel. 2003. The effects of saltcedar (Tamarix spp.) on resident songbirds in riparian habitat of the Salton Sea. Pages 65-71 in P. M. Faber, editor. California riparian systems: processes and floodplain management, ecology, and restoration. 2001 Riparian Habitat and Floodplains Conference Proceedings. Riparian Habitat Joint Venture, Sacramento, California.

Holmes, J. J., J. Spence, and M. K. Sogge. 2005. Birds of the Colorado River in Grand Canyon: a synthesis of status, trends, and dam operation effects. Pages $123-138$ in S. P. Gloss, J. E. Lovich, and T. E. Melis, editors. The state of the Colorado River ecosystem. U.S. Geological Survey Circular 128. U.S. Geological Survey, Reston, Virginia.

Howe, W. H. 1986. Status of the yellow-billed cuckoo (Coccyzus americanus) in New Mexico-1986. Final report (contract 516.6-75-09) to the New Mexico Department of Game and Fish, Santa Fe, New Mexico.

Hughes, J. M. 1999. Yellow-billed cuckoo (Coccyzus americanus). In A. Poole, and F. Gill, editors. The birds of North America, no. 418. The Birds of North America, Inc., Philadelphia, Pennsylvania.

Hunter, W., R. Ohmart, and B. Anderson. 1988. Use of exotic saltcedar (Tamarix chinensis) by birds in arid riparian systems. Condor 90:113-123.

Intermountain West Joint Venture. 2005. Intermountain West Joint Venture: coordinated bird conservation plan. Version 1.0. West Valley City, Utah (available from http://www.iwjv.org/plans.htm) accessed 2 April 2007.

Isacch, J. P., N. O. Maceira, M. S. Bo, M. R. Demaria, and S. Peluc. 2005. Bird-habitat relationship in semi-arid grasslands and exotic pastures in the west pampas of Argentina. Journal of Arid Environments 62:267-283.

Johnson, M. J., J. A. Holmes, and R. Weber. 2006. Yellow-billed cuckoo distribution and abundance, habitat use, and breeding ecology in select habitats of the Roosevelt Habitat Conservation Plan, 20032006. Final Report submitted to the Salt River Project, Colorado Plateau Research Station, Northern Arizona University, Flagstaff.

Johnson, M. J., J. A. Holmes, C. Calvo, I. Samuels, S. Krantz, and M. K. Sogge. 2007. Yellow-billed cuckoo distribution, abundance, and habitat use along the Lower Colorado and tributaries, 2006 Annual Report. USGS Open File Report 2007-1097. U.S. Geological Survey, Reston, Virginia.

Jones, Z. F., and C. E. Bock. 2005. The Botteri's Sparrow and exotic Arizona grasslands: an ecological trap or habitat regained? Condor 107:731-741.

Kus, B. E., and P. P. Beck. 2003. Pages 396-406 in P. M. Faber, editor. California riparian systems: processes and floodplain management, ecology, and restoration. 2001 Riparian Habitat and Floodplains Conference Proceedings. Riparian Habitat Joint Venture, Sacramento, California.

Livingston, M. F., and S. D. Schemnitz. 1996. Summer bird/vegetation associations in tamarisk and native habitat along the Pecos River, southeastern New Mexico. Pages 171-180 in D. W. Shaw and D. M. Finch, technical coordinators. Desired future conditions for southwestern riparian ecosystems: bringing interests and concerns together. USDA General Technical Report RM-GTR-272. USDA Forest Service, Rocky Mountain Research Station, Fort Collins, Colorado.

Lloyd, J. D., and T. E. Martin. 2005. Reproductive success of Chestnutcollared Longspurs in native and exotic grassland. Condor 107: 363-374.

Lodge, D. M., S. Williams, H. J. MacIsaac, K. R. Hayes, B. Leung, S. Reichard, et al. 2006. Biological invasions: recommendations 
for U.S. policy and management. Ecological Applications 16: 2035-2054.

Lovich, J. E., and R. C. De Gouvenain. 1998. Saltcedar invasion in desert wetlands of the Southwestern United States: ecological and political implications. Pages 447-467 in S. I. Majumdar, E. W. Miller, and F. J. Brenner, editors. Ecology of wetlands and associated systems. The Pennsylvania Academy of Science.

McKernan, R. L., and G. Braden. 2002. Status, distribution, and habitat affinities of the Southwestern Willow Flycatcher along the Lower Colorado River. Final report submitted to U.S. Bureau of Reclamation and U.S. Fish and Wildlife Service. San Bernardino County Museum, Redlands, California.

Nelson, S. M., and R. Wydoski. 2008. Riparian butterfly (Papilionoidea and Hesperioidea) assemblages associated with Tamarix-dominated, native vegetation-dominated, and Tamarix removal sites along the Arkansas River, Colorado, USA. Restoration Ecology 16:168-179.

Ortega, Y. K., K. S. McKelvey, and D. L. Six. 2006. Invasion of an exotic forb impacts reproductive success and site fidelity of a migratory songbird. Oecologia 149:340-351.

Owen, J. C., M. K. Sogge, and M. D. Kern. 2005. Habitat and gender differences in the physiological condition of breeding Southwestern Willow Flycatchers. Auk 122:1261-1270.

Remes, V .2003. Effects of exotic habitat on nesting success, territory density, and settlement patterns in the Blackcap (Sylvia atricapilla). Conservation Biology 17:1127-1133.

Rich, T. D., C. J. Beardmore, H. Berlanga, P. J. Blancher, M. S. W. Bradstreet, G. S. Butcher, et al. 2004. Partners in Flight North American Landbird Conservation Plan. Cornell Lab of Ornithology, Ithaca, New York. Partners in Flight website (Version: March 2005) (available from http://www.partnersinflight.org/cont_plan/) accessed 2 April 2007.

Robertson, B. A., and R. L. Hutto. 2006. A framework for understanding ecological traps and an evaluation of existing evidence. Ecology 87:1075-1085.

Rodriguez, L. F. 2006. Can invasive species facilitate native species? Evidence of how, when, and why these impacts occur. Biological Invasions 8:927-939.

Rosenberg, K. V., R. D. Ohmart, W. C. Hunter, and B. W. Anderson. 1991. Birds of the Lower Colorado River Valley. University of Arizona Press, Tucson.

Schmidt, K. A., L. C. Nelis, N. Briggs, and R. S. Ostfeld. 2005. Invasive shrubs and songbird nesting success: effects of climate variability and predator abundance. Ecological Applications 15:258-265.

Shafroth, P. B., J. R. Cleverly, T. L. Dudley, C. van Riper III, E. P. Weeks, and J. N. Stuart. 2005. Control of Tamarix in the Western United States: implications for water salvage, wildlife use, and riparian restoration. Environmental Management 35:231-246.

Shafroth, P. B., V. B. Beauchamp, M. K. Briggs, K. Lair, M. L. Scott, and A. A. Sher. 2008. Planning riparian restoration in the context of Tamarix control in western North America. Restoration Ecology 16:97-112.

Sogge, M. K., D. L. Felley, and M. Wotawa. 2005. A quantitative model of avian community and habitat relationships along the Colorado River in the Grand Canyon. Pages 161-192 in C. van Riper III, and D. Mattson, editors. The Colorado Plateau II: biophysical, socioeconomic, and cultural research. University of Arizona Press, Tucson.
Sogge, M. K., E. H. Paxton, and A. A. Tudor. 2006. Saltcedar and Southwestern Willow Flycatchers: lessons from long-term studies in central Arizona. Pages 238-241 in C. Aguirre-Bravo, P. J. Pellicane, D. P. Burns, and S. Draggan, editors. Monitoring science and technology symposium: unifying knowledge for sustainability in the Western hemisphere. 20-24 September 2004, Denver, Colorado. Proceedings RMRS-P-42CD. U.S. Department of Agriculture, Forest Service, Rocky Mountain Research Station, Fort Collins, Colorado.

Sonoran Joint Venture Technical Committee. 2006. In C. J. Beardmore, editor. Bird Conservation Plan. Version 1.0. Sonoran Joint Venture, Tucson, Arizona (available from http://www.sonoranjv.org/ planning01.html) accessed 2 April 2007.

Stromberg, J. C., and M. K. Chew. 2002. Foreign visitors in riparian corridors of the American Southwest: is xenophytophobia justified? Pages 195-219 in B. Tellman, editor. Invasive exotic species in the Sonoran Region. University of Arizona Press, Tucson.

Travis, J. R. 2005. Statewide Yellow-billed cuckoo survey: 2004. Report to New Mexico Department of Game and Fish, Santa Fe, New Mexico.

USFWS (U.S. Fish and Wildlife Service). 2002. Southwestern Willow Flycatcher (Empidonax traillii extimus) final recovery plan. U.S. Fish and Wildlife Service, Albuquerque, New Mexico.

USFWS (U.S. Fish and Wildlife Service). 2004. A blueprint for the future of migratory birds. Migratory bird program strategic plan 0042014. Appendix 4: birds of management concern. Migratory Birds and State Programs, Arlington, Virginia (available from http:// migratorybirds.fws.gov/mbstratplan/GPRAMBSpecies.pdf) accessed 2 April 2007.

van Horne, B. 1983. Density as a misleading indicator of habitat quality. Journal of Wildlife Management 47:893-901.

van Riper, C. III, K. L. Paxton, C. O’Brien, P. B. Shafroth, and L. J. McGrath. 2008. Rethinking avian response to Tamarix on the lower Colorado River: a threshold hypothesis. Restoration Ecology 16: 155-167.

Walker, H. A. 2006. Southwestern avian community organization in exotic tamarisk: current patterns and future needs. Pages 274-286 in C. Aguirre-Bravo, P. J. Pellicane, D. P. Burns, and S. Draggan, editors. Monitoring science and technology symposium: unifying knowledge for sustainability in the Western hemisphere. 20-24 September 2004, Denver, Colorado. Proceedings RMRS-P-42CD. U.S. Department of Agriculture, Forest Service, Rocky Mountain Research Station, Fort Collins, Colorado.

Williams, S. O. III, and J. R. Travis. 2003. History, distribution, and status of the Yellow-billed cuckoo in New Mexico. Abstract from paper presented to the 75th annual meeting of the Cooper Ornithological Society. USGS Colorado Plateau Research Station, Flagstaff, Arizona.

Woodward, H. D., S. H. Stoleson, and D. M. Finch. 2003. Yellow-billed cuckoo on the Gila National Forest: presence-absence, abundance and habitat. Final report for the 2002 field season. USDA Forest Service, Rocky Mountain Research Station, Albuquerque, New Mexico.

Yong, W., and D. M. Finch. 1997. Migration of the Willow Flycatcher along the middle Rio Grande. Wilson Bulletin 109:253-268.

Zavaleta, E. 2000. Valuing ecosystem services lost to Tamarix invasion in the United States. Pages 261-300 in H. A. Mooney, and R. J. Hobbs, editors. Invasive species in a changing world. Island Press, Washington, D.C. 